\title{
RECHTSREGEL
}

Jurnal Ilmu Hukum Vol 1, No 2 Desember 2018

P-ISSN 2622-6235, E-ISSN 2622-6243,

rjih_fh@unpam.co.id

\section{EKSEKUSI PUTUSAN TANPA HADIRNYA TERGUGAT (Studi Kasus CV. Global Mandiri Sejahtera)}

\author{
Susanto \\ Fakultas Ekonomi Universitas Pamulang \\ Email : susantogss@yahoo.com
}

Received: - / Revised: - / Accepted: Des 2018

\begin{abstract}
Hubungan bisnis antar perusahaan sudah pasti yang ingin dicapai adalah keuntungan dan kesinambungan kerjasama usaha. Namun demikian faktanya tidak semua kerjasama bisnis menguntungkan walaupun sudah direncanakan sedemikian rupa serta sudah dibuat sebuah konsep kerjasama yang detail dan saling menguntungkan. Begitu pula yang dialami oleh CV. Global Mandiri Sejahtera sebuah perusahaan produsen susu kedelai yang telah menjalin kerjasama dengan PT. Transindo Jaya Komara. Permasalahan tersebut hingga bersengketa di Pengadilan Negeri tangerang. Metode pendekatan yang dipakai adalah pendekatan yuridis normatif. Hasil penelitian menghasilkan bahwa akibat hukum dari pelaksanaan eksekusi putusan tanpa hadirnya tergugat (verstek) adalah meskipun putusan diputus tanpa hadirnya tergugat tetap dapat dilaksanakan secara sah menurut hokum.
\end{abstract}

\section{Kata Kunci : Eksekusi, Putusan Pengadilan}

\begin{abstract}
The business relationship between companies is certain to achieve is the profit and continuity of business cooperation. However, the fact is not all business cooperation is profitable even though it has been planned in such a way and has made a concept of detailed cooperation and mutual benefit. Similarly, experienced by CV. Global Mandiri Sejahtera is a soybean producer company that has cooperated with PT. Transindo Jaya Komara. The problem was to dispute in the Tangerang District Court. The approach method used is a normative juridical approach. The results of the study resulted that the legal consequences of the execution of the decision without the presence of the defendant (verstek) were that even though the verdict was decided without the presence of the defendant it could still be implemented legally according to the law.
\end{abstract}

Keywords: Execution, Court Decision 


\section{PENDAHULUAN}

Hubungan bisnis antar perusahaan sudah pasti yang ingin dicapai adalah keuntungan dan kesinambungan kerjasama usaha. Namun demikian faktanya tidak semua kerjasama bisnis menguntungkan walaupun sudah direncanakan sedemikian rupa serta sudah dibuat sebuah konsep kerjasama yang detail dan saling menguntungkan. Begitu pula yang dialami oleh CV. Global Mandiri Sejahtera sebuah perusahaan produsen susu kedelai yang telah menjalin kerjasama dengan PT. Transindo Jaya Komara.

Kerjasama yang dituangkan dalam sebuah perjanjian Surat Perjanjian "SURAT AKAD SYARIKAT MUDHARABAH nomor : 001/P/GOMARS/SMG/XII/2011 ANTARA CV. GLOBAL MANDIRI SEJAHTERA Cabang Semarang dengan PT. TRANSINDO JAYA KOMARA tanggal 30 Desember 2011, menjadi wujud kerjasama antara keduanya. Berdasaarkan Surat Kesepakatan dalam Perjanjian antara Para Penggugat dengan Para Tergugat dalam Surat AKAD SYARIKAT MUDHARABAH nomor : 001/P/GO-MARS/SMG/XII/2011.

Atas perjanjian tersebut di atas telah di sepakati oleh kedua belah pihak dengan Pasal 3 jumlah yang dipesan oleh PT. Transindo Jaya Komara yaitu sebanyak 400.000 Box, dan hal itu telah di setujui oleh CV. Global Mandiri Sejahtera untuk di kirim kepada PT. Transindo Jaya Komara di Tangerang Banten dengan sistem pembayaran di lakukan secara Tunai atau pembayaran di tempat apabila barang tersebut telah sampai di tempat tujuan yaitu PT. Transindo Jaya Komara yang seharusnya berdasarkan perjanjian telah di bayar lunas. ${ }^{1}$.

Namun demikian faktanya pihak PT. Transindo Jaya Komara tidak melakukan kewajibannya sampai pada akhirnya pihak CV. Global Mandiri Sejahtera mengajukan gugatan di Pengadilan Negeri Tangerang terhadap PT. Transindo Jaya Komara dengan nomor register perkara No. 218/Pdt.G/2013/PN.Tng.

1 Salinan Putusan Perkara Pengadilan Negeri Tangerang, Perkara Perdata No.218/Pdt.G/2013/PN.Tng. tanggal 28 Oktober 2013, halaman 2-3, diolah. 
Atas gugatan CV. Global Mandiri Sejahtera tersebut pihak PT. Transindo Jaya Komara tidak pernah hadir dalam persidangan meskipun sudah beberapa kali dipanggil baik melalui panggilan yang ditujukan kepada alamat PT. Transindo Jaya Komara maupun panggilan melalui media massa. Akhirnya majelis hakim yang memeriksa perkara tersebut mengeluarkan putusan dengan tanpa hadirnya tergugat (verstek).

Selama persidangan berlangsung pihak CV. Global Mandiri Sejahtera mengajukan sita jaminan untuk menjamin agar gugatan tidak illusioner belaka terhadap beberapa asset milik PT. Transindo Jaya Komara. Oleh Majelis Hakim pemeriksa perkara tersebut sita jaminan yang dimohonkan oleh CV. Global Mandiri Sejahtera dinyatakan sah dan berharga yang sebelumnya melalui proses peletakan sita jaminan oleh Juru Sita Pengadilan Nageri Tangerang.

Pada saat proses Sita Jaminan pihak PT. Transindo Jaya Komara tidak hadir meskipun telah dilakukan pemanggilan secara sah dan patut. Sehingga pada saat pelaksanaan sita jaminan tidak dapat dikonfirmasi kepada pihak PT. Transindo Jaya Komara mengenai kebenaran objek yang diletakkan sita jaminan.

Setelah perkara tersebut diputus oleh Majelis Hakim Pengadilan Negeri Tangerang tanggal 28 Oktober 2013 kemudian Juru Sita Pengadilan Negeri Tangerang memberitahukan kepada PT. Transindo Jaya Komara ke alamat, namun oleh karena perusahaan telah pindah panggilan tersebut diberikan kepada Kantor Kepala Desa tempat domisili PT. Transindo Jaya Komara dan pemberitahuan putusan pun melalui media masa.

Bahwa setelah putusan berkekuatan hukum tetap pihak CV. Global Mandiri Sejahtera mengajukan permohonan eksekusi. Eksekusi tersebut merupakan eksekusi atas permintaan para pihak. M. Yahya Harahap S.H, dalam bukunya Hukum Acara Perdata tentang gugatan, persidangan, penyitaan, pembuktian hlm. 782 menyebutkan bahwa : Atas permintaan salah satu pihak maupun atas permintaan bersama kedua belah pihak, dapat dilakukan pemeriksaan setempat. Hak para pihak tentang ini ditegaskan dalam 
pasal $153 \mathrm{HIR}, 180 \mathrm{RBG}$ atau pasal $211 \mathrm{Rv}$, bahwa atas permintaan para pihak, dapat diadakan pemeriksaan setempat. Permintaan itu dapat diajukan salah satu pihak apabila pihak lawan membantah kebenaran letak, luas, atau batas-batas tanah objek sengketa. Maka untuk memperoleh kejelasan yang pasti, sangat penting dilakukan pemeriksaan setempat. Seperti yang dapat dilihat pada Putusan No.274 K/Sip/1976 maupun No.436 K/Sip/1974, hakim tingkat kasasi berpendapat, letak dan ukuran luas atau batas-batas tanah terperkara belum jelas dan pasti, sehingga dianggap sangat urgen melakukan pemeriksaan setempat. $^{2}$

Eksekusi sebagai tindakan hukum yang dilakukan oleh pengadilan kepada pihak yang kalah dalam suatu negara, merupakan aturan dan tata cara lanjutan dari proses pemeriksaan perkara. Oleh karena itu eksekusi tiada lain daripada tindakan yang berkesinambungan dari keseluruhan proses hukum acara perdata. Eksekusi merupakan suatu kesatuan yang tidak terpisah dari pelaksanaan tata tertib beracara yang terkandung dalam HIR atau RBG. Bagi setiap orang yang ingin mengetahui pedoman aturan eksekusi, harus merujuk ke dalam aturan perundang-undangan yang diatur dalam HIR atau RBG.

Namun dalam pelaksanaanya eksekusi yang dilaksanakan Pengadilan Negeri Tangerang terhadap permasalahan antara CV. Global Mandiri Sejahtera dengan PT. Transindo Jaya Komara menghadapi berbagai kendala dan permasalahan yang menghambat pemenuhan amar putusan yang telah berkekuatan hukum tetap. Oleh Karenanya Penulis Merasa Penting untuk Mengangkat Judul dengan Tema “ KONSEP EKSEKUSI TANPA HADIRNYA TERGUGAT (Studi Kasus CV Global Mandiri Sejahtera).”

\section{PERMASALAHAN}

Dari uraian latar belakang masalah di atas, penulis tertarik mengangkat masalah yang diteliti yaitu:

\footnotetext{
${ }^{2}$ M. Yahya Harahap, Hukum Acara Perdata tentang gugatan, persidangan, penyitaan, pembuktian, dan putusan Pengadilan, Jakarta: Sinar Grafika, cet.8, 2008, h. 782.
} 
1. Bagaimana hambatan dan kendala dalam pelaksanaan eksekusi Putusan Pengadilan Negeri dari Putusan Tanpa Hadirnya Tergugat?

2. Bagaimana akibat hukum dari pelaksanaan eksekusi putusan tanpa hadirnya tergugat (verstek)?

\section{TUJUAN DAN MANFAAT PENELITIAN}

Penelitian ini dilakukan dengan tujuan untuk:

1. Mengetahui hambatan dan kendala pelaksanaan eksekusi putusan tanpa hadirnya tergugat (verstek).

2. Mengetahui akibat hukum dari pelaksanaan eksekusi putusan tanpa hadirnya tergugat (verstek).

Penelitian ini diharapakan dapat memberikan manfaat :

1. Bagi pendidikan atau akademisi, penelitian ini dapat memperkaya khasanah kepustakaan bahan pertimbangan bagi pihak-pihak yang mengadakan penelitian yang menyangkut eksekusi putusan perkara perdata.

2. Bagi praktisi hukum dapat memperkaya pemahaman mengenai eksekusi putusan pengadilan dalam perkara perdata.

\section{METODE PENELITIAN}

Metode pengumpulan data yang kami gunakan untuk menunjang dan memperkaya penelitian ini adalah dengan :

1. Metode Pendekatan

Metode pendekatan yang dipakai adalah pendekatan yuridis normatif yaitu pendekatan yang menggunakan legis positivis, yang menyatakan bahwa hukum identik dengan norma-norma tertulis yang dibuat dan diundangkan oleh lembaga atau pejabat yang berwenang. Selain itu konsepsi ini memandang hukum sebagai suatu sistem normatif yang 
bersifat otonom, tertutup dan terlepas dari kehidupan masyarakat. ${ }^{3}$ Metode pendekatan yuridis normatif digunakan dengan tujuan untuk menganalisis dasar hukum pelaksanaan eksekusi putusan perdata.

2. Sumber data

Penelitian hukum yang bersifat normatif selalu menitikberatkan pada data sekunder. Data sekunder pada penelitian dapat dibedakan menjadi :

a. Bahan Hukum primer merupakan bahan hukum yang bersifat autoritatif artinya memiliki suatu otoritas, mutlak dan mengikat Bahan hukum primer terdiri dari peraturan dasar, peraturan perundang-undangan, catatan resmi, lembar Negara penjelasan, risalah, putusan hakim dan yurisprudensi. ${ }^{4}$ Dalam hal ini penulis menggunakan bahan hukum primer antara lain Herziene Inlandsch Reglemen (HIR), Undang-Undang Nomor 14 Tahun 1985 adalah Undang-Undang tentang Mahkamah Agung perubahan pertama dengan Undang-Undang Nomor 5 Tahun 2004, kemudian dirubah lagi dengan perubahan kedua dengan Undang-Undang Nomor 3 Tahun 2009, Undang-Undang Nomor 2 Tahun 1986 adalah UndangUndang tentang Peradilan Umum, dirubah dengan Undang-Undang Nomor 8 Tahun 2004, kemudian mengalami perubahan kedua dengan Undang-Undang Nomor 49 Tahun 2009.

b. Bahan Hukum Sekunder, yaitu bahan-bahan yang memberikan penjelasan mengenai bahan hukum primer, berupa hasil karya dari kalangan hukum dalam bentuk buku-buku atau artikel. Bahan hukum sekunder digunakan dengan pertimbangan bahwa data primer tidak dapat menjelaskan realitas secara lengkap sehingga diperlukan bahan hukum primer dan sekunder sebagai data sekunder untuk melengkapi deskripsi suatu realitas.

3. Metode Pengumpulan data

${ }^{3}$ Peter Mahmud Marzuki, Penelitian Hukum, Kencana Prenada Media Group, Jakarta, 2005, hal.37.

${ }^{4}$ Ibid, hal. 113. 
Data sekunder diperoleh dengan melakukan inventarisasi peraturan perundang-undangan, dokumen resmi, dan literatur yang kemudian dicatat berdasarkan relevansinya dengan pokok permasalahan untuk kemudian dikaji sebagai suatu kajian yang utuh.

\section{PEMBAHASAN}

\section{Eksekusi Putusan}

Suatu perkara perdata diajukan oleh pihak yang bersangkutan kepada pengadilan untuk mendapatkan pemecahan atau penyelesaian. Pemeriksaan perkara memang diakhiri dengan putusan, akan tetapi dengan dijatuhkan putusan saja belumlah selesai persoalannya. Putusan tersebut harus bisa dilaksanakan atau dijalankan, oleh karena itu putusan hakim mempunyai kekuatan eksekutorial, yaitu kekuatan untuk dilaksanakan apa yang ditetapkan dalam putusan itu secara paksa oleh alat-alat Negara. Adapun yang memberi kekuatan eksekutorial pada hakim adalah kepala putusan yang berbunyi "Demi Keadilan Berdasarkan Ketuhanan Yang Maha Esa".

Adapun dari beberapa para ahli yang berpendapat mengenai eksekusi sebagai berikut :

a. Elfrida R Gultom dan Markoni, yang dimaksud eksekusi ialah melaksanakan secara paksa putusan pengadilan dengan bantuan kekuatan umum, guna menjalankan putusan pengadilan yang telah memperoleh kekuatan hukum tetap. ${ }^{6}$

b. M. Yahya H. eksekusi adalah merupakan tindakan hukum yang dilakukan oleh pengadilan kepada pihak yang kalah dalam suatu perkara, merupakan aturan tata cara lanjutan dari proses pemeriksaan

${ }^{5}$ Elfrida R Gultom dan Markoni, Hukum Acara Perdata, (Jakarta:Mitra Wacana Media,2014), hal. 89.

6 ibid, hal. 90. 
yang berkesinambungan dari keseluruhan proses hukum acara perdata. $^{7}$

c. R. Subekti eksekusi adalah pelaksanaan suatu putusan yang sudah tidak dapat diubah lagi itu, ditaati secara sukarela oleh pihak yang bersengketa. Jadi di dalam makna perkataan eksekusi sudah mengandung arti pihak yang kalah mau tidak mau harus mentaati putusan itu secara sukarela, sehingga putusan itu harus dipaksakan kepadanya dengan bantuan kekuatan umum. Yang dimaksud dengan kekuatan umum adalah polisi bahkan kalau perlu militer (angkatan bersenjata). ${ }^{8}$

d. Djazuli Bachar adalah Melaksanakan putusan pengadilan, yang tujuannya tidak lain adalah untuk mengefektifkan suatu putusan menjadi suatu prestasi yang dilakukan dengan secara paksa. Usaha berupa tindakan-tindakan paksa untuk merealisasikan putusan kepada yang berhak menerima dari pihak yang dibebani kewajiban yang merupakan eksekusi. ${ }^{9}$

e. R. Supomo adalah hukum yang mengatur cara dan syarat-syarat yang dipakai oleh alat-alat Negara guna membantu pihak yang berkepentingan untuk menjalankan putusan hakim, apabila pihak yang kalah tidak bersedia memenuhi bunyinya putusan dalam waktu yang ditentukan. ${ }^{10}$

\section{Putusan Tanpa Hadirnya Tergugat}

Putusan verstek merupakan putusan yang dijatuhkan oleh Majelis Hakim tanpa hadirnya tergugat dan tanpa alasan yang sah meskipun telah dipanggil secara resmi dan patut. Putusan verstek ini merupakan

${ }^{7}$ M. Yahya Harahap, Ruang Lingkup Permasalahan Eksekusi Bidang Perdata, cet.3, (Jakarta:PT. Gramedia,1991), hal. 1

${ }^{8}$ R. Subekti, Hukum Acara Perdata, cet. 3, (Bandung; Binacipta, 1989) hal.130.

${ }^{9}$ Djazuli Bachar, Eksekusi Putusan Perkara Perdata, Segi Hukum dan Penegakan Hukum, Akademika. Pressindo, Cet.1, Jakarta, 1986, hal. 6

${ }^{10}$ R. Supomo., Hukum Acara Perdata Pengadilan Negeri, cet. 9, (Jakarta :PT.Pradnya Paramita, 1986), hal 119 
pengecualian dari acara persidangan biasa sebagai akibat ketidakhadiran tergugat atas alasan yang tidak sah.

Dalam acara verstek tergugat dianggap ingkar menghadiri persidangan tanpa alasan yang sah dan tergugat dianggap mengakui sepenuhnya secara murni dan bulat semua dalil gugatan penggugat. Putusan verstek hanya dapat dijatuhkan dalam hal tergugat atau para tergugat tidak hadir pada hari sidang pertama.

Putusan tersebut tampak kurang adil bagi tergugat karena dijatuhkan tanpa kehadirannya. Sementara perkara tidak mungkin digantung tanpa akhir yang pasti atau harus segera diselesaikan. Walaupun demikian bukan berarti pintu telah tertutup bagi tergugat. Tergugat masih memiliki jalan untuk mendapatkan pengadilan dengan cara melakukan upaya hukum biasa yaitu perlawanan terhadap putusan verstek. ${ }^{11}$

Pasal 129 ayat (1) HIR atau pasal $83 \mathrm{Rv}$ menegaskan : "Tergugat yang sedang dihukum sedang ia tidak hadir (verstek) dan tidak menerima putusan itu, dapat mengajukan perlawanan atas putusan itu". ${ }^{12}$

Jadi apabila terhadap tergugat dijatuhkan putusan verstek, dan dia keberatan atasnya, tergugat dapat mengajukan perlawanan (verzet), bukan upaya banding. Terhadap putusan verstek, tertutup upaya banding, oleh karena itu permohonan banding terhadapnya cacat formil, dengan demikian tidak dapat diterima. Dalam Putusan MA ditegaskan bahwa permohonan banding yang diajukan terhadap putusan verstek tidak dapat diterima, karena upaya hukum terhadap verstek adalah perlawanan (verzet).

\section{Putusan Yang Tidak Dapat Dieksekusi}

Putusan Non executable (Putusan Yang Tidak Dapat Dieksekusi) merupakan suatu putusan yang telah berkekuatan hukum tetap tetapi tidak dapat dilakukan eksekusi. Suatu putusan yang telah berkekuatan

11 Nur Rasaid, Hukum Acara Perdata, (Jakarta, Sinar Grafika, 1996), 61

12 Soesilo, RIB/HIR dengan Penjelasan, (Bogor ; Politeia, 1985), 86 
hukum tetap dapat dinyatakan non executable oleh Ketua Pengadilan apabila:

a. Putusan yang bersifat deklaratoir dan konstitutif. Putusan deklaratoir yaitu putusan yang amarnya menyatakan suatu kedaaan sebagai keadaan yang sah menurut hukum. Sementara putusan bersifat konstitutif yaitu putusan yang amarnya menciptakan suatu keadaan baru;

b. Barang yang akan dieksekusi tidak berada di tangan Tergugat/Termohon eksekusi. Apabila obyek eksekusi berada di tangan pihak ketiga maka dapat diajukan non executable;

c. Barang yang akan dieksekusi tidak sesuai dengan barang yang disebutkan di dalam amar putusan;

d. Amar putusan tersebut tidak mungkin untuk dilaksanakan;

e. Ketua Pengadilan tidak dapat menyatakan suatu putusan non executable sebelum seluruh proses atau acara eksekusi dilaksanakan, kecuali, yang tersebut pada butir 1. Penetapan non executable harus didasarkan pada Berita Acara yang dibuat oleh juru sita yang diperintahkan untuk melaksanakan (eksekusi) putusan tersebut;

f. Penetapan non executable bersifat final dan tidak dapat diajukan keberatan. ${ }^{13}$

\section{Analisis Kasus}

Dari hasil penelitian menunjukkan bahwa Putusan Pengadilan Negeri Tangerang Nomor : 218/Pdt.G/2013/PN.Tng, tanggal 28 Oktober 2013 bersifat kondemnator adalah putusan yang amar atau diktumnya mengandung unsur "Penghukuman", yang dalam amar putusan selengkapnya menyebutkan sebagai berikut :

- Menyatakan Para Tergugat yang telah dipanggil secara sah dan patut, tidak hadir dipersidangan;

13 Nur Hariandi Tusni, S.H., M.H. Putusan mNon Executable dalam http://www.luwuraya.net/2012/10/putusan-non-executable/ diakses tanggal 21 November 2018. 
- Menerima dan mengabulkan gugatan Para Penggugat untuk sebahagian, secara tanpa dihadiri oleh Para Tergugat (Verstek);

- Menyatakan Surat Akad Syarikat Mudharabah Antara CV. Global Mandiri Sejahtera dengan PT. Transindo Jaya Komara (Koperasi Langit Biru) Nomor : 001/P/GO-MARS/SMG/XII/2011, tertanggal 30 Desember 2011 tetap sah berlaku dan mengikat para pihak (Para Penggugat dengan Para Tergugat);

- Menyatakan Para Tergugat telah ingkar janji/Ingkar Janji terhadap Surat Akad Syarikat Mudharabah Antara CV. Global Mandiri Sejahtera dengan PT. Transindo Jaya Komara (Koperasi Langit Biru) Nomor : 001/P/GO-MARS/SMG/XII/2011tanggal 30 Desember 2011;

- Menghukum Para Tergugat secara Tanggung Renteng membayar kepada Para Penggugat atas kerugian yang diderita oleh Para Penggugat yaitu :

a. kerugian materiil : Rp. 20.000.000.000,00 ( Dua Puluh Milyar rupiah),

b. keuntungan yang sedyanya diperoleh Rp.200.000.000,00 (dua ratus juta rupiah) setiap bulan, terhitung sejak gugatan ini didaftarkan April 2013 sampai dengan putusan ini yaitu selama 7 bulan adalah menjadi 7 x Rp. 200.000.000,00 = Rp.1.400.000.000,00 (satu milyar empat ratus juta rupiah);

c. kerugian imateriil 2 (dua) orang Penggugat: 2 x Rp. 1.000.000.000,00 ( satu milyar rupiah ) adalah Rp. 2.000.000.000,00 (dua milyar rupiah);

d. sehingga total semuanya adalah sebesar Rp. 23.400.000.000,00 ( Dua Puluh Tiga Milyar Empat Ratus Juta rupiah),

- Menyatakan Sita Jaminan (Conservatoir Beslag) yang telah diletakkan terhadap harta benda Para Tergugat berupa : .... Dst.

Adalah sah dan berharga;

- Menghukum Para Tergugat untuk membayar biaya perkara yang hingga putusan ini ditaksir adalah sebesar Rp.2.783.000,- (dua juta tujuh ratus delapan puluh tiga ribu rupiah);

- Menolak gugatan Para Penggugat yang selain dan selebihnya. ${ }^{14}$

Adapun amar putusan yang bersifat kondemnator adalah :

- Menghukum Para Tergugat secara Tanggung Renteng membayar kepada Para Penggugat atas kerugian yang diderita oleh Para Penggugat yaitu :

a. kerugian materiil : Rp. 20.000.000.000,00 ( Dua Puluh Milyar rupiah),

14 Salinan Putusan Perkara Pengadilan Negeri Tangerang, Perkara Perdata No.218/Pdt.G/2013/PN.Tng. tanggal 28 Oktober 2013. 
b. keuntungan yang sedyanya diperoleh Rp.200.000.000,00 (dua ratus juta rupiah) setiap bulan, terhitung sejak gugatan ini didaftarkan April 2013 sampai dengan putusan ini yaitu selama 7 bulan adalah menjadi $7 \mathrm{x}$ Rp. 200.000.000,00 = Rp.1.400.000.000,00 (satu milyar empat ratus juta rupiah);

c. kerugian imateriil 2 (dua) orang Penggugat: $2 x \mathrm{Rp}$. 1.000.000.000,00 ( satu milyar rupiah ) adalah Rp. 2.000.000.000,00 (dua milyar rupiah);

d. sehingga total semuanya adalah sebesar Rp. 23.400.000.000,00 ( Dua Puluh Tiga Milyar Empat Ratus Juta rupiah),

Selain bersifat kondemnator putusan tersebut diputus tanpa hadirnya tergugat sebagaimana amarnya yang menyebutkan :

- Menyatakan Para Tergugat yang telah dipanggil secara sah dan patut, tidak hadir dipersidangan;

- Menerima dan mengabulkan gugatan Para Penggugat untuk sebahagian, secara tanpa dihadiri oleh Para Tergugat (Verstek);

Selanjutnya putusan tersebut telah terdapat pernyataan sah dan berharga sita jaminan yang telah diletakkan sehingga apabila putusan tersebut dieksekusi termasuk dalam sita eksekusi yang tidak langsung yaitu sita eksekusi yang berasal dari sita jaminan yang telah dinyatakan sah dan berharga dan dalam rangka eksekusi otomatis berubah menjadi sita eksekusi.

Pada tanggal 31 Oktober 2013, Jurusita Pengadilan Negeri tangerang telah memberitahukan putusan tersebut kepada pihak PT, Transindo Jaya Komara melalui harian Rakyat Merdeka tertanggal 31 Oktober 2013. Bahwa terhitung sejak pemberitahuan putusan tersebut pihak PT. Transindo Jaya Komara tidak ada itikad baik untuk melaksanakan putusan secara sukarela, meskipun putusan tersebut telah berkekuatan hukum tetap.

Sesuai ketentuan Pasal 196 HIR, jika pihak yang dikalahkan tidak mau atau lalai memenuhi keputusan dengan baik, maka pihak yang dimenangkan mengajukan permintaan kepada ketua pengadilan supaya keputusan itu dilaksanakan Kemudian ketua akan memanggil pihak yang 
kalah itu serta menegurnya, supaya ia memenuhi keputusan itu dalam waktu yang ditentukan oleh Ketua itu selama-lamanya delapan hari.

Jika pihak yang dikalahkan mau dengan sukarela memenuhi isi putusan pengadilan tentu eksekusi tidak perlu dilaksanakan. Kalau mereka mempunyai kesadaran hukum yang tinggi tentu mereka akan mematuhi amar putusan pengadilan. Jadi kalau mereka tidak mau memenuhi bunyi putusan perlu adanya upaya peningkatan kesadaran hukum mereka.

Oleh karenanya jika mereka tidak mau memenuhi secara sukarela bunyi putusan maka setelah ada permintaan dari penggugat atau pihak yang menang, Ketua Pengadilan akan menegur mereka agar dalam waktu 8 hari mau memenuhi putusan tersebut. Setelah 8 hari peringatan aanmaning dilampaui maka sejak saat itulah berlaku upaya eksekusi. Selama eksekusi belum dilaksanakan masih terbuka bagi tergugat untuk memenuhi putusan secara sukarela sehingga membebaskan mereka dari biaya eksekusi.

Pada tanggal 5 Desember 2013, oleh Ketua Pengadilan Negeri Tangerang sesuai dengan Relaas Panggilan Tegoran (Aanmaning), Nomor : 63/Pen.Eks/2013/PN.Tng. Jo. No.218/Pdt.G/2013/PN.Tng, Para Tergugat/Para Termohon Eksekusi telah dipanggil untuk diberikan tegoran, namun tidak hadir pada waktu yang telah ditentukan dan melalui Harian Rakyat Merdeka Tanggal 18 Desember 2013.

Selanjutnya meskipun sudah diberikan aanmaning oleh Ketua Pengadilan Negeri Tangerang, pihak PT. Transindo Jaya Komara tetap tidak melaksanakan isi putusan oleh karenanya pihak CV. Global Mandiri Sejahtera mengajukan permohonan eksekusi. Kemudian Ketua Pengadilan Negeri Tangerang mengeluarkan Penetapan Nomor : 63/PEN.EKS/2013/PN.TNG Jo. No.218/PDT.G/2013/ PN.TNG tanggal 30 Januari 2014 yang isinya memerintahkan kepada Panitera Pengadilan Negeri Tangerang untuk melaksanakan Lelang Eksekusi (Penjualan Dimuka Umum) dengan perantaraan Kantor Pelayanan Kekayaan Dan Lelang Serpong Tangerang terhadap asset milik PT. Transindo Jaya 
Komara yang terletak di wilayah hukum Pengadilan Negeri Tangerang dan Meminta bantuan kepada Ketua Pengadilan Negeri Rangkasbitung untuk memerintahkan kepada Panitera/Jurusita Pengadilan Negeri Rangkasbitung untuk memerintahkan kepada Panitera Pengadilan Negeri Rangkasbitung untuk melaksanakan Lelang Eksekusi (Penjualan Dimuka Umum) dengan perantaraan Kantor Pelayanan Kekayaan Dan Lelang setempat terhadap asset milik PT. Transindo Jaya Komara yang terletak di wilayah hukum Pengadilan Negeri Rangkasbitung.

Eksekusi tersebut merupakan eksekusi pembayaran uang dan untuk memaksa Tereksekusi melunasi jumlah uang tersebut kepada pemohon eksekusi, dengan jalan menjual lelang harta kekayaan tereksekusi. Tata cara pelaksanaannya diawali dengan peringatan (aanmaning) dan Sita Eksekusi (executorial-beslag). Dalam proses peringatan pihak Tereksekusi oleh Ketua Pengadilan dipanggil untuk diperingatkan agar dalam waktu paling lambat 8 hari harus melaksanakan bunyi putusan tersebut.

Sita Eksekusi Ketua Pengadilan Negeri Tangerang tersebut sesuai Pasal 197 HIR atau Pasal 208 RBG. Sita Eksekusi (Eksekiitorial beslag) ini dikeluarkan oleh Ketua Pengadilan Negeri Tangerang setelah tereksekusi belum memenuhi buniyi putusan dalam waktu yang telah ditentukan oleh ketua ataupun tereksekusi tersebut tidak menghadap ketua sekalipun telah dipanggil dengan sah.

Disini jelas jika panggilan itu tidak sah maka ketua tidak akan mengeluarkan perintah sita eksekusi. Panggilan disampaikan kepada pihak yang dipanggil itu sendiri di tempat tinggal/domisili PT. Transindo Jaya Komara di Desa Solear, Kecamatan Balaraja, Kabupaten Tangerang, Provinsi Banten.

Relaas panggilan tersebut ternyata tidak ditandatangani oleh pihak PT. Transindo Jaya Komara maka oleh jurusita panggilan disampaikan kepada Kepala Desa Solear dan ditandatangani oleh Kepala Desa Solear serta dibubuhi cap Kepala Desa Solear. 
a. Hambatan dan kendala dalam eksekusi putusan tanpa hadirnya tergugat

Pada tanggal 30 Januari 2014 Ketua Pengadilan Negeri Tangerang mengeluarkan Penetapan Nomor : 63/PEN.EKS/2013/PN.TNG Jo. No.218/PDT.G/2013/ PN.TNG. yang isinya memerintahkan kepada Panitera Pengadilan Negeri Tangerang untuk melaksanakan Lelang Eksekusi (Penjualan Dimuka Umum) dengan perantaraan Kantor Pelayanan Kekayaan Dan Lelang Serpong Tangerang terhadap asset milik PT. Transindo Jaya Komara yang terletak di wilayah hukum Pengadilan Negeri Tangerang dan Meminta bantuan kepada Ketua Pengadilan Negeri Rangkasbitung untuk memerintahkan kepada Panitera/Jurusita Pengadilan Negeri Rangkasbitung untuk memerintahkan kepada Panitera Pengadilan Negeri Rangkasbitung untuk melaksanakan Lelang Eksekusi (Penjualan Dimuka Umum) dengan perantaraan Kantor Pelayanan Kekayaan Dan Lelang setempat terhadap asset milik PT. Transindo Jaya Komara yang terletak di wilayah hukum Pengadilan Negeri Rangkasbitung.

Atas penetapan tersebut kemudian Panitera Pengadilan Negeri Tangerang melakukan lelang terhadap asset milik PT. Transindo Jaya Komara berupa Tanah seluas 1500 M2 dan Bangunan Gudang 500 M2 yang terletak di RT.006/01, Desa Cangkudu, KM 2, Kecamatan Balaraja, Kabupaten Tangerang, Banten.

Harta tidak bergerak milik PT. Transindo Jaya Komara tersebut terletak di wilayah hukum Pengadilan Negeri Tangerang sehingga lelang dilakukan di Kantor Pelayanan Kekayaan Dan Lelang Serpong Tangerang dengan mekanisme pihak Pengadilan Negeri Tangerang meminta bantuan lelang kepada Kantor Pelayanan Kekayaan Dan Lelang Serpong Tangerang dan selanjutnya oleh Kantor Pelayanan Kekayaan Dan Lelang Serpong Tangerang tersebut terhadap objek tanah tersebut dilakukan pengecekan apakah sudah 
bersertipikat atau belum di Kantor Pertanahan Kabupaten Tangerang. Setelah dilakukan penelitian ternyata objek tanah tersebut telah bersertipikat sesuai dengan Sertipikat Hak Milik atas nama Jaya Komara.

Dalam pelaksanaan lelang pihak Pengadilan Negeri Tangerang telah melakukan pemanggilan terhadap para pihak yang berperkara dan mengumumkan di media masa. Dalam perjalanannya ternyata diperoleh informasi bahwa terdapat perkara lain yang melakukan sita eksekusi terhadap asset tersebut yaitu PT. Esa Bumindo, yang berkedudukan di Jalan Raya Pasar Kemis, Ruko Bumi Indah, Blok RD, No. 1,2 Keluarahan Kutajaya, Kecamatan Pasar Kemis, Tangerang, Banten.

Perusahaan tersebut ternyata mempunyai hubungan hukum dengan PT. Transindo Jaya Komara dimana perkaranya Nomor : 222/PID.SUS/2013/PN.TNG. telah diputus tanggal 25 Juni 2013 dan sudah mempunyai kekuatan hukum tetap. Sita eksekusi terhadap benda tidak bergerak milik PT. Transindo Jaya Komara dilakukan oleh PT. Esa Bumindo berdasarkan Penetapan Ketua Pengadilan Negeri Tangerang, Nomor : 06/PEN.EKS/2014/PN.TNG Jo. No.445/PDT.G/2012/PN.TNG. tanggal 22 Mei 2014.

Oleh karena terdapat bidang yang sama maka pihak CV. Global Mandiri Sejahtera pada tanggal 1 Juli 2014 mengajukan bantahan terhadap penetapan tersebut yang diregister oleh Pengadilan Negeri Tangerang dengan Nomor : 385/Pdt.Bth/2014/PN.Tng. dengan Terbantah PT. Esa Bumindo.

Selanjutnya mengenai lelang yang dilakukan oleh Pengadilan Negeri Tangerang dengan meminta bantuan/delegasi kepada Pengadilan Negeri Rangkasbitung terhadap benda tidak bergerak milik PT. Transindo Jaya Komara berupa : Tanah milik PT. Transindo Jaya Komara (Koperasi Langit Biru) yang terletak di Jalan Raya Rangkas Bitung Km. 10 RT.005/001, Desa Mekarsari, Kecamatan 
Rangkasbitung, Kabupaten Lebak, Banten dan yang terletak di Desa Mekarsari seluas 800 M2. 11 bidang Tanah dan Bangunan terletak di Desa Sukarendah, Kecamatan Warunggunung, Kabupaten Lebak, Provinsi Banten.

Benda tidak bergerak milik PT. Transindo Jaya Komara tersebut yang berhasil atau telah dilelang adalah Tanah milik PT. Transindo Jaya Komara (Koperasi Langit Biru) yang terletak di Jalan Raya Rangkas Bitung Km. 10 RT.005/001, Desa Mekarsari, Kecamatan Rangkasbitung, Kabupaten Lebak, Banten dan Tanah milik PT. Transindo Jaya Komara (Koperasi Langit Biru) yang terletak di Desa Mekarsari seluas 800 M2.

Sementara terhadap benda bergerak milik PT. Transindo Jaya Komara berupa Tanah dan Bangunan 11 bidang yang, terletak di Desa Sukarendah, Kecamatan Warunggunung, Kabupaten Lebak, Provinsi Banten, belum bisa dilelang karena terdapat perlawanan dan gugatan dari pihak lain, yang diregister oleh Pengadilan Negeri Tangerang Nomor :249/Pdt.Plw/2014/PN.TNG, tanggal 02 Mei 2014 dan Nomor : 458/Pdt.G/2014/PN.TNG, tanggal 25 Juli 2014 yang keduanya diajukan oleh Hajjah Nur Asiah, dimana Hajjah Nur Asiah mendalilkan bahwa tanah tersebut di atas miliknya.

\section{b. Akibat Hukum eksekusi Putusan Tanpa Hadirnya Tergugat}

Dasar hukum mengenai eksekusi putusan verstek diatur dalam Pasal 128 HIR, jo Pasal 195 HIR. Putusan Verstek tidak dapat dieksekusi sebelum lewat tenggang 14 hari dari tanggal pemberi tahuan putusan, putusan verstek harus diberitahukan kepada tergugat. tenggang waktu mengajukan verstek diatur dalam Pasal 129 ayat (2) HIR, menurut ketentuan tersebut patokan tenggang waktu yang diterapkan sebagai landasan umum adalah 14 hari dari tanggal pemberitahuan putusan verstek kepada penggugat. Eksekusi terhadap putusan verstek baru dapat dijalankan apabila lewat tenggang waktu mangajukan verstek baru, dan selama tenggang masih berlaku, tergugat tidak mengajukan perlawanan 
(verzet). Eksekusi baru dapat dijalankan apabila putusan tersebut telah memperoleh kekuatan hukum yang tetap, Pasal 128 ayat (1) HIR.

Berdasarkan analisa data perkara Nomor : 218/Pdt.G/2013/PN.Tng. telah diputuskan oleh Majelis Hakim Pengadilan Negeri Tangerang tanggal 28 Oktober 2013 dan telah diberitahukan kepada Para Tergugat oleh Juru Sita Pengadilan Negeri Tangerang tanggal 31 Oktober 2013 melalui harian Rakyat Merdeka tertanggal 31 Oktober 2013.

Putusan Verstek dapat di eksekusi sebelum lewat 14 hari atas alasan sangat perlu dapat dilaksanakaneksekusi putusan verstek, meskipun tenggang waktu mengajukan perlawanan belum lewat, pengecualian tersebut diatur dalam Pasal 128 ayat (2) HIR. Ketentua Pasal 180 HIR yangmemberi wewenang kepada ketua Pengadilan Negeri melaksanakan putusan lebih dahulu (vitvoerbaar bij voorraad) meskipun tergugat mengajukan perlawanan atau banding.Terdapat keadaan yang sangat perlu syarat ini disebut dengan tegas dalam Pasal 128 ayat (2) HIR dengan mempergunakan keadaan yang sangat perlu. Aada perintah daripenggugat agar putusan verstek dilaksanakan terlebih dahulu meskipun belum lewat 14 hari dari tanggal pemberitahuan. Permohonan harus dibarengi dengan alsan-alasan yang benar-benar memenuhi katagori. Dari syarat-syarat diatas yang dianggap sah dan memenuhi syarat putusan verstek yang bersifat komulatif bukan alternatif.

Dari hasil penelitian penulis setelah di umumkan melalui harian Rakyat Merdeka tertanggal 31 Oktober 2013 sampai tenggang waktu yang ditentukan yaitu 14 hari, Para Tergugat sama sekali tidak mengajukan perlawanan atau verzet. Oleh karenanya Pihak Penggugat yang menang mengajukan eksekusi putusan.

Oleh Ketua Pengadilan Negeri Tangerang pengajuan eksekusi tersebut dikabulkan dengan mengeluarkan Relaas Panggilan Tegoran (Aanmaning), Nomor : 63/Pen.Eks/2013/PN.Tng. Jo. No.218/Pdt.G/2013/PN.Tng, Para Tergugat/Para Termohon Eksekusi telah dipanggil untuk diberikan tegoran, namun tidak hadir pada waktu yang 
telah ditentukan dan melalui Harian Rakyat Merdeka Tanggal 18 Desember 2013.

Hal ini berarti meskipun putusan perkara Nomor : 218/Pdt.G/2013/PN.Tng. diputus tanpa hadirnya Tergugat, tetap dapat dilaksanakan eksekusi. Hal ini berakibat asset milik Para Tergugat yang menjadi Para Termohon Eksekusi dapat dilakukan lelang atau penjualan dimuka umum yang hasilnya untuk menutupi atau membayar kerugian Para Penggugat.

Akibat hukum eksekusi Putusan Pengadilan Negeri Tangerang Nomor : 218/Pdt.G/2013/PN.Tng, tanggal 28 Oktober 2013 adalah bahwa eksekusi tersebut menjadikan asset milik Para Tergugat sebagai pihak yang kalah yang telah dinyatakan sah dan berharga sita jaminan yang telah diletakkan bisa dilelang atau dijual dimuka umum yang hasilnya untuk membayar kerugian yang diderita oleh Para Penggugat selaku pihak yang menang dan apabila kerugian tersebut belum mencukupi maka terhadap asset yang lain dapat dimintakan sita eksekusi. Hal ini merujuk pada ketentuan Pasal 1131 KUHPerdata berisi sebagai berikut : "Segala kebendaan si berutang, baik yang bergerak maupun yang tak bergerak baik yang sudah ada maupun yang baru aka nada di kemudian hari menjadi tanggungan untuk segala perikatan perseorangan”.

\section{KESIMPULAN}

1. Hambatan dan kendala pelaksanaan eksekusi putusan tanpa hadirnya tergugat (verstek) dalam perkara yang diteliti adalah adanya pelaksanaan eksekusi yang tidak dihadiri oleh termohon eksekusi mengakibatkan aset termohon eksekusi tidak diketahui secara pasti sehingga menimbulkan adanya perlawanan dari pihak ketiga yang menghambat pelaksanaan eksekusi. Lamanya waktu oleh karena dalam memanggil termohon eksekusi harus secara sah dan patut dan hal ini mempengaruhi biaya operasional yang dikeluarkan oleh pemohon eksekusi. 
2. Akibat hukum dari pelaksanaan eksekusi putusan tanpa hadirnya tergugat (verstek) adalah meskipun putusan diputus tanpa hadirnya tergugat tetap dapat dilaksanakan secara sah menurut hukum dengan syarat putusan tersebut memenuhi persyaratan-persyaratan tertentu yaitu putusan tersebut telah berkekuatan hukum tetap, Ketua Pengadilan Negeri telah mengeluarkan putusan berupa penetapan eksekusi, Ketua Pengadilan Negeri telah memanggil termohon eksekusi untuk diberikan tegoran (aanmaning) sebanyak dua kali namun tidak dilaksanakan secara sukarela, selanjutnye dengan menunjuk Panitera Pengadilan Negeri, Ketua Pengadilan Negeri memerintahkan untuk dilaksanakan eksekusi dengan sebelumnya memanggil para pihak termasuk Termohon Eksekusi secara patut dan sah.

\section{SARAN}

1. Diperlukan sebuah aturan yang mengatur secara tegas terhadap pelaksanaan putusan tanpa hadirnya tergugat dimana peraturan yang selama ini digunakan diatur dengan cara seperti halnya menjalankan putusan pada umumnya. Hal ini untuk mengurangi hambatan-hambatan yang dihadapi pada saat pelaksanaan eksekusi.

2. Diperlukan suatu kesadaran dari pihak yang terlibat dalam perjanjian bisnis agar apabila terjadi perselisihan agar hadir dalam persidangan sehingga dalam pelaksanaan putusan tidak mendapatkan hambatanhambatan.

\section{DAFTAR PUSTAKA}

Djazuli Bachar, 1986, Eksekusi Putusan Perkara Perdata, Segi Hukum dan Penegakan Hukum, Akademika. Pressindo, Cet.1, Jakarta.

Elfrida R Gultom dan Markoni, 2014, Hukum Acara Perdata, Mitra Wacana Media, Jakarta.

M. Yahya Harahap, 2008 Hukum Acara Perdata tentang gugatan, persidangan, penyitaan, pembuktian, dan putusan Pengadilan, Sinar Grafika, cet.8, Jakarta. 
---------, 1991, Ruang Lingkup Permasalahan Eksekusi Bidang Perdata, cet.3, PT. Gramedia,1991), hal, Jakarta.

Nur Rasaid, 1996, Hukum Acara Perdata, Sinar Grafika, Jakarta.

Peter Mahmud Marzuki, 2005, Penelitian Hukum, Kencana Prenada Media Group, Jakarta.

R. Subekti, 1989, Hukum Acara Perdata, cet. 3, Binacipta, Bandung.

R. Supomo, 1986, Hukum Acara Perdata Pengadilan Negeri, cet. 9, PT.Pradnya Paramita, Jakarta.

Soesilo, 1985, RIB/HIR dengan Penjelasan, Politeia, Bogor.

Nur Hariandi Tusni, S.H., M.H. Putusan mNon Executable dalam http://www.luwuraya.net/2012/10/putusan-non-executable/ diakses tanggal 21 November

2018. 
